\title{
PENERAPAN SHARIA COMPLIANCE DALAM PEMBIAYAAN MURABAHAH (Studi Kasus BPRS Al-Madinah Tasikmalaya)
}

\author{
Rizkha Badaniah ${ }^{1}$ \\ Gista Rismayani ${ }^{2}$ \\ Email: rizkhabadaniah123@gmail.com \\ Universitas Perjuangan Tasikmalaya ${ }^{1,2}$
}

\begin{abstract}
Abstrak:Penelitian ini membahas tentang kepatuhan syariah tehadap produk pembiayaan murabahah yang ada di BPRS Al-Madinah Tasikmalaya, dimana penelitian ini menggunakan metode kualitatif deskriptif yang bertujuan untuk mengetahui penerapan sharia compliance atau kesesuaian terhadap prinsip syariah yang berdasarkan Fatwa DSN-MUI pada produk pembiayaan murabahah di BPRS Al-MadinahTasikmalaya.Jenispenelitian yang digunakan pada penelitian ini yaitu metode deskriptif kualitatif, jenis data yang digunakan yaitu data primer dan data sekunder, sedangkan teknik pengumpulan data yang digunakan penelitian ini yaitu: wawancara, observasi dan dokumentasi. Teknik analisis yang digunakan pada penelitian ini yaitu pengumpulan data, display data dan penarikan kesimpulan. Penelitian ini menghasilkan bahwa pelaksanaan pembiayaan murabahah di BPRS Al-Madinah sudah sesuai dengan sharia compliance berdasarkan fatwa DSN-MUI yaitu tidak adanya riba, maisir, gharar, haram dan terdapat Dewan Pengawas Syariah (DPS).
\end{abstract}

Kata kunci: sharia compliance (fatwa DSN-MUI), dan pembiayaan murabahah.

Abstract: his study discusses sharia thinking about murabahah financing products in BPRS Madinah Tasikmalaya, where this research uses descriptive qualitative methods that aim to ensure sharia compliance or conformity to sharia principles based on the DSN-MUI Fatwa on murabahah financing products at BPRS Al-Madinah. Tasikmalaya.The type of research used in this research is descriptive qualitative method, the type of data used is primary data and secondary data, while the techniques used in this research are: interviews, observation and documentation. The analysis technique used in this research is data, data display and withdrawal.This research results that the implementation of murabahah financing at BPRS Madinah is in accordance with sharia compliance based on the DSN-MUI fatwa, namely the absence of usury, maisir, gharar, haram and there is a Sharia Supervisory Board (DPS).

Keywords: sharia compliance (DSN-MUI fatwa), and murabaha financing

\section{PENDAHULUAN}

Perkembangan ekonomi syariah pada saat ini mengalami kemajuan yang sangat pesat, keberadaan bank dalam suatu Negara sangatlah dibutuhkan karena bank mempunyai peranan yang 
sangat penting dalam sistem perekonomian suatu negara. Di Indonesia, Bank Syariah yang pertama kali didirikan pada tahun 1992 ialah Bank Muamalat yang melaksanakan kegiatan usahanya berdasarkan prinsip syariah. Undang-Undang yang mengatur perbankan syariah dengan prinsip bagi hasil ialah Undang-Undang Nomor 7 tahun 1992 tentang perbankan dan Peraturan pemerintah Nomor 27 Tahun 1992 tentang Bank berdasarkan prinsip bagi hasil.

Salah satu sistem yang harus ada di lembaga keuangan syariah adalah kepatuhan pada prinsip syariah (sharia compliance). Berdasarkan Peraturan Bank Indonesia Nomor 13/2/PBI/2011 tentang Pelaksanaan Fungsi Kepatuhan Bank Umum, yang dimaksud kepatuhan adalah nilai, perilaku, dan tindakan yang mendukung terciptanya kepatuhan terhadap ketentuan Bank Indonesia dan peraturan perundang-undangan yang berlaku, termasuk Prinsip Syariah bagi Bank Umum Syariah dan Unit Usaha Syariah. Sehingga kepatuhan syariah (sharia compliance) merupakan bentuk ketaatan bank syariah dalam memenuhi prinsip-prinsip syariah dalam operasionalnya. Prinsip tersebut harus diterapkan dalam akad yang digunakan terhadap produk-produk bank syariah salah satunya yaitu pembiayaan murabahah.

Perbankan syariah dalam menjalankan kegiatan operasionalnya yaitu menghimpun dana dari masyarakat dan menyalurkan kembali kepada masyarakat dalam bentuk pembiayaan yang menggunakan prinsip bagi hasil dan jual beli. Produk pembiayaan yang paling diminati adalah pembiayaan murabahah, sebagaimana dapat dilihat dari Tabel1.1.

Tabel 1.1 Perbandingan Produk PembiayaanBank Syariah di Indonesia

\begin{tabular}{r|lllll} 
No. & Pembiayaan & \multicolumn{4}{c}{ Tahun } \\
\cline { 3 - 6 } 1. & Murabahah & 2015 & 2016 & 2017 & 2018 \\
2. & Mudharabah & 15.698 & 16.241 & 18.114 & 16.920 \\
3. & Musyarakah & 60.816 & 78.511 & 101.585 & 129.653 \\
4. & Qard & 3.951 & 4.731 & 6.349 & 826 \\
5. & Istishna & 770 & 878 & 1.189 & 1.594
\end{tabular}

Sumber: Ojk.go.id (data diolah)

Berdasarkan Tabel 1.1 Data Statistik Perbankan Syariah (SPS) selama 4 tahun terakhir dapat disimpulkanbahwa pembiayaan murabahah lebih unggul dibandingakan dengan pembiayaan yang lainnya. Sebagaimana dijelaskan peneliti terdahulu oleh Kaira (2014) bahwa pembiayaan murabahah adalah pembiayaan yang paling sering digunakan dan lebih unggul dibandingkan produk-produk pembiayaan syariah lainnya, karena pembiayaan murabahah memiliki risiko yang rendah, lebih aman dan proses dan prakteknya lebih mudah. Pembiayaan Murabahah tidak hanya mendominasi di Bank Umum Syariah tetapi juga di Bank Pembiayaan Rakyat Syariah (BPRS).

Berdasarkan penelitian terdahulu oleh Waluyo (2016), Hafidz, (2018), Nurbaety (2019), tentang variabel yang sama yaitu kepatuhan syariah (shari'a compliance) dan pembiayaan Murabahah dari hasil penelitian tersebut dapat disimpulkan bahwa pembiyaan murabahah dilembaga keungaan syariah masih belum sesuai dengan sharia compliance karena adanya 
keterbatasan terutama sumber daya manusia dibank syariah menyebabkan penegakan kepatuhan syariah masih belum maksimal. Pentingnya penelitian ini bagi masyarakat agar dapat mengetahui mekanisme pembiayaan pada lembaga keuangan syariah berdasarkan prinsip syariah sehingga masyarakat dapat mengetahui dan memahami implementasi dari lembaga keuangan syariah, dan bagi pihak yang bersangkutan dapat lebih meningkatkan prnsip-prinsip syariah dalam menjalankan praktek pembiayan pada lembaga keuangan syariah. Sehingga penelitian ini mengidentifikasi penerapan sharia compliance dalam proses pembiayaan Murabahah, ingin mengetahui apakah proses pembiayaannya sudah sesuai dengan prinsip syariah pada BPRS Al-Madinah Tasikmalaya. Selain itu, peneliti tertarik melakukan penelitian tentang studi penerapan sharia compliance dalam pembiayaan murabahah. Sehingga penulis tertarik untuk meneliti tentang "Penerapan Sharia Compliance Dalam Pembiayaan Murabahah."

\section{METODE PENELITIAN}

Objek Penelitian ini adalah sharia compliance dan pembiayaan murabahah. sedangkan Subjek penetian ini adalah BPRS Al-Madinah Tasikmalaya.Metode penelitian yang digunakan pada penelitian ini adalah metode kualitatif yang berbentuk deskriptif yaitu peneliti berusaha mendeskripsikan atau menggambarkan tentang penerapan sharia compliance dalam pembiayaan murabahah di BPRS Al-Madinah Tasikmalaya. Jenis data yang digunakan dalam peneliti ini adalah data primer Data primer yaitu data yang diperoleh dari sumber pertama secara langsung dengan mewawancarai pihak-pihak BPRS Al-Madinah Tasikmalaya dan Nasabah BPRS AlMadinah Tasikmalaya. Penelitian ini menggunakan uji keabsahan data yaitu: Uji Validitas internal (credibility), Uji Validitas Internal (Credibility) merupakan uji kebenaran data, uji credibility pada penelitian ini dilakukan dengan cara triangulasi. Triangulasi merupakan pengecekan data dengan berbagai cara dan dari beberapa sumber. Triangulasi pada penelitian ini menggunakan dua jenis triangulasi yaitu:

1. Triangulasi sumber data merupakan mencari informasi dari berbagai sumber atau metode perolehan misalnya wawancara yang di dukung dengan bukti dokumen sehingga data yang diperoleh lebih akurat.

2. Triangulasi teori merupakan sebuah rumusan informasi dari hasil akhir penelitian dengan membandingkan informasi yang diperoleh dengan teori agar menghasilakan keismpulan yang sifatnya tidak bias

\section{Hasil pembahasan}

1. Penerapan sharia compliance pada pembiayaan murabahah di BPRS Al-Madinah Tasikmalaya 
Berdasarkan hasil wawancara penulis dengan bagian marketing dan DPS BPRS AlMadinah Tasikmalaya bahwasanya penerapan pembiayaan murabahah di BPRS Al-Madinah sebagai berikut:Menurut bagian marketing irwan Nurdiana Okta sebagai berikut:

"pembiayaan murabahah ini adalah akad jual beli jadi keperluan nasabah digunakan untuk apa, jika komodity lebih dari satu missal untuk pembelian bahan bangunan sehingga pihak bank memerlukan RAB terlebih dahulu. Pengumpulan persyaratan diambil oleh Account Officer kemudian diberikan kebagian analis, dan dianalisis dalam segi 5C yaitu: Carakteristic, Capasity, Credibality, Condisy, Comoditas. Setelah lulus dari 5C maka akad pembiayaan murabahah dapat berlangsung"

Pernyataan bagian marketing dipertegas oleh ketua DPS BPRS Al-Madinah H.Muhammad Aminudin menyatakan sebagai berikut:

"murabahah itu bukan rasio kalau jual beli itu misalnya ada besaran harga jual beli yang pertama tentu akidani orang yang berakad, barang yang dijual misalnya ini mobil perbankan belinya 100 jt dalam sisi agama dibolehkan kemudian orang berdagangkan beruntung dalam segi agama dibolehkan jadi harus transparan terbuka ada pembicaraan awal ok keuntungannya jadi dua jelas berapa dan barangnya maski diperlihatkan harus jelas".

Pelaksanaan penerapan sharia compliance pada Bank Pembiayaan Rakyat Syariah dalam proses pembiayaan terdapat beberapa tahapan yang harus dilalui oleh nasabah. Adapun tahapan yang harus dilakukan sebagai berikut :

\section{Tahap pengajuan pembiayaan murabahah}

Tahap pengajuan atau permohonan pembiayaan murabahahCalon Pembeli (nasabah) mengajukan permohonan pembiayaan dengan akad murabahah kepada pihak BPRS AlMadinah Tasikmalaya setelah mengajukan permohonan calon nasabah melengkapi persyaratan-persyaratan yang diajukan oleh bank dan mengisi formulir yang disediakan oleh pihak bank, setelah syarat sudah dipenuhi oleh calon nasabah, surat permohonan pembiayaan dicatat pada buku administrasi dan menandatangani pada buku tersebut.Setelah itu bank menganalisis syarat yang sudah dipenuhi oleh calon nasabah dan melakukan investigasi untuk dapat ditindaklanjuti apakah permohonan bisa diterima atau ditolak.

Adapun persyaratan yang harus dipenuhi oleh nasabah sebagai berkut :

Tabel 4.1 persyaratan pembiayaan murabahah

\begin{tabular}{|l|l|l|}
\hline \multicolumn{3}{|c|}{ Persyaratan } \\
\hline Keterangan & $\begin{array}{c}\text { Karyawa } \\
\text { n swasta }\end{array}$ & Wirausaha \\
\hline
\end{tabular}




\begin{tabular}{|r|c|c|}
\hline Formulir pengajuan & $\checkmark$ & $\checkmark$ \\
\hline Fotocopy E-KTP Suami/Istri & $\checkmark$ & $\checkmark$ \\
\hline Pas Foto 3 x 4 Suami/Istri masing- & $\checkmark$ & $\checkmark$ \\
masing & & \\
\hline Fotocopy Kartu Keluarga (KK) & $\checkmark$ & $\checkmark$ \\
\hline Fotocopy Surat Nikah & $\checkmark$ & $\checkmark$ \\
\hline Fotocopy Rekening & $\checkmark$ & $\checkmark$ \\
Listrik/Telepon/PAM/SPPT PBB & & \\
\hline Slip Gaji 3 Bulan terakhir & $\checkmark$ & \\
\hline Surat Keterangan Pegawai & $\checkmark$ & \\
\hline Surat Rekomendasi dari atasan & $\checkmark$ & \\
\hline Surat Keterangan Usaha & & $\checkmark$ \\
\hline Jaminan & $\checkmark$ & $\checkmark$ \\
\hline & &
\end{tabular}

Tahap pengajuan atau permohonan pembiayaan murabahah apakah sudah sesuai dengan sharia compliance atau tidak berikut penjelasannya:

1. Tidak ada Riba dalam transaksi

Tahap ini calon nasabah mendatangi BPRS Al-Madinah dan calon nasabah mengisi formulir dan persyaratan yang harus dipenuhi. Apabila pihak bank sudah menerima permohonan calon nasabah maka akan adanya musyawarah antara bank dan calon nasabah untuk membicarakan besarnya margin/bagi hasil yang didapatkan.Ketua DPS H. Muhammad Aminudin menjelaskan sebagai berikut:

"perbedaan bank syariah dengan bank Konvensional itu jelas pada akadnya, bank syariah itu transparan jelas seperti apa akadnya dan keuntunganyapun disepakati oleh kedua belah pihak sedangkan bank konvensional menggunakan debitur, debitur tidak mau tau kesusahan para nasabah, yang harus nasabah lakukan adalah melunasinya pada saat jatuh tempo sedangkan bank syariah akan memberikan rukhsoh atau keringanan kepada nasabah apabila terjadinya musibah yang dialami. Selain itu pada saat menabung diperbankan syariah uang nasabah tidak dipakai sehingga ketika nasabah ingin mengambil uang, uang masih dalam keadaan utuh sedangkan pada bank konvensional ketika kita menabung maka pada saat kita ingin mengambil uang tersebut maka aka nada pengurangan nilai atau penambahan nilai itulah yang bisa menyebabkan riba".

2. Tidak ada gharar dalam transaksi bank

Apabila kita liat dari sisi tidak adanya unsur gharar dalam tahap permohonan. Pada saat calon nasabah mengajukan permohonan ke bank, calon nasabah melengkapi persyaratan yang di ajukan oleh bank terlebih dahulu dan pihak bank menganalisis persyaratan tersebut dan 
bank menginformasi semua informasi yang harus diinformasikan kepada nasabah.Ketua DPS H. Muhammad Aminudin menjelaskan sebagai berikut:

"Gharar itu kan penipuan atau tipu menipu barang jelek dibilang baik speak/bicara awal begini tapi yah begitu apapun penipuan apapun yg disampaikan berarti tidak sesuai dengan kenyataan".

3. Tidak boleh objek transaksi yang dilarang dalam syariah (haram).

Pada tahap permohonan, barang atau objek yang diperjual belikan oleh bank tidak mengandung unsur haram misalkan: Alkohol, sabu-sabu, judi, babi dll. Hal ini dipertegas oleh ketua DPS BPRS Al-Madinah Tasikmalaya H.Muhammad Aminudin menyatakan sebagai berikut:

"Haram sesuatu yang dalam perspektif agama dilarang oleh agama jadi keberkahan itu tidak hanya keuntngan semata.Apabila kita menjual produk yang mengandung unsur maisir maka akan merusak bank syariah itu sendiri”.

4. Tidak boleh ada ketidakadilan bagi pihak lain (dzalim).

Jika dilihat dari unsur dzalim dalam tahap pengajuan atau permohonan bank menginformasikan terlebih dahulu semua informasi kepada nasabah dan bank juga memusyawarahkan margin/bagi hasil untuk pembiayaan murabahah. Ketua DPS H.Muhammad Aminudin menyatakan sebagai berikut:

"Dzalim itu wayughari mahaliki jadi makanya sejak awal mesti transparan untuk menghindari kedzaliman dan untuk bagi Ada aturan dari bank tersendiri namun juga di musyawarahkan kembali ke nasabah dan disepakati bersama"

5. Terdapat Dewan Pengawas Syariah (DPS)

Tugas DPS adalah mengawasi semua aktivitas operasional perbankan syariah agar sesuai dengan prinsip-prinsip syariah. Seperti yang dijelaskan oleh ketua DPS H. Muhammad Aminudin sebagai berikut:

"Sejak kami di SK-kan menjadi DPS sesuai dengan yg tertuang diregulasi bagaimna tentang tugas dan fungsi peran pokok DPS bagaimana kesesuaian syariah diperbankan syariah dan bentuk pengawasan yang dilakukan yang pertama kita ada istilah kode etik tata kelola tata kerja itu kita 1 bulan sekali untuk rapat rutin memantau progress kemudian 6 bulan sekali laporan per-dps pusat ojk sudah diatur dalam regulasinya jadi kami tidak bisa melanggar aturan dan untuk melakukan pengawasan juga ada tim audit yang memeriksa setiap satu tahun maksimal 2 kali atau per 6 bulan sekali”.

\section{Tahap pelaksanaan pembiayaan murabahah.}

Pada saat tahap pelaksanaan pembiayaan murabahahini calon nasabah mengumpulkan persyaratan yang diajukan oleh bank dan memberikan lampiran berupa rencana anggaran biaya (RAB) kepada bagian marketing.RAB pada BPRS Al-Madinah terbagi menjadi dua bagian yaitu yang pertama RAB untuk modal kerja seperti bahan bangunan dan yang kedua yaitu untuk 
pembiayaan konsumtif seperti pembelian mobil, motor dll. Setelah nasabah mengumpulkan semua persyaratan termasuk $\mathrm{RAB}$, berkas akan diproses dibagian analis untuk menganalisi kelaykan, kewajaran atau validasi surat permohonan dan lampiran yang diajukan oleh nasabah, apabila telah wajar atau layak maka berkas akan masuk ke komite dan ditandatangani dan disetujui oleh direksi setalah disetuji dan ditandatangani berkas masuk ke bagian administrasi untuk melakukan penjadwalan akad murabahah.

Pada tahap pelaksanaan pembiayaan murabahah, untuk mengetahui apakah pelaksanaan pembiayaan murabahah sudah sesuai dengan sharia compliance atau belum dapat diketahui dengan penjelasan berikut :

1. Tidak ada Gharar dalam transaksi

Pada saat pelaksanaan pembiayaan murabahah, pihak BPRS akan mengecek atau menganalisis terlebih dahulu keakuratan data calon nasabah dan menginformasikan segala sesuatu yang berhubungan dengan pembiayaan murabahah. Selain itu rukun jual beli yang digunakan jelas sesuai dengan prinsip syariah seperti yang dikatakan oleh bagian marketing BPRS Al-Madinah (Irman Nurdiana Okta, 2020) sebagai berikut:

"rukun jual beli murabahah yaitu adanya pihak yang bertransaksi (bank dan nasabah), objek yang dibeli dan ijab qabul."

Kemudian dipertegas oleh ketua DPS (H. Muhammad Aminudin, 2020) menyatakan sebagai berikut:

"Tertuang dalam akad, pengikatannya setelah betul-betul tahapan yg dilalui, yah sesuai dengan regulasi jual beli adanya penjual, penjual inikan bank, pembeli itu nasabah dan barang yang akan di perijual belikan."

2. Akad atau kontrak yang digunakan sesuai dengan prinsip syariah

Ketika melakukan akad atau kontrak yang digunakan harus sesuai dengan akad yang dibutuhkan.Akad yang dibutuhkan dalam akad jual beli yaitu menggunakan akad murabahah.Akad murabahah ini merupakan akad yang sering dilakukan dan sangat diminati oleh nasabah karena biasanya akad ini membeli barang-barang konsumtuf seperti kendaraan (mobil, motor, dsb) ataupun untuk membeli rumah.Selain itu akad atau kontrak juga harus memenuhi rukun dan syarat jual beli.seperti yang dikatakan oleh Irman Nurdiana Okta sebagai berikut:

"Rukun jual beli murabahah yaitu adanya pihak yang bertransaksi (bank dan nasabah), objek yang dibeli dan ijab qabul Untuk kendaran seperti mobil dan motor maka BPRS terlebih dahulu membeli asset namun untuk bahan bangunan menggunakan akad wakalah bin murabahah".

Kemudian dipertegas oleh H. Muhammad Aminudinsebagai berikut :

"kesesuaian akad-akad yang ada di bank sesuai dengan hasil dewan nasional sesuai dengan pusat kan ada Fatwa no 4 tahun 2000. Termasuk berkaitan dengan format 
akad itu nanti ada kelengkapan-kelengkapan lain ada SOP kan acuannya itu, jadi kalau ada produk akad diperbankan syariah melanggar atau tidak sesuai karena dalam hal ini pemeriksaan ojk berkala itu pasti ada konsekuensi.ketika melakukan akad jelas harus ada barang yang dibeli yang menjual itu al-madinah dan calon nasabah dan barang yang harus diperjualbelikan harus transparan terus sighat akad baru perjanjian dan ditangani Sesuai akad dan rukun jual beli dari fatwa MUI."

3. Produk yang dibiayai tidak bertentangan dengan syariah

Tahap ini yaitu Produk yang dijual belikan oleh BPRS Al-Madinah sesuai dengan syariah dan produk yang dihalalkan oleh agama. Hal ini dikatakan oleh ketua DPS Al-Madinah yaitu bapak H. Muhammad Aminudin sebagai berikut:

"Apapun jenis usaha yg dibolehkan agama misal bisnis jual beli yang tidak dibolehkan yaitu narkoba, sabu, jual beli mobil yang bodong itu haram gak boleh meskipun menguntungkan dalam segi agama".

4. Terdapat DPS dalam kegiatan Operasional

Pada tahap ini DPS bertugas untuk memeriksa semua dokumen transaksi dan akad yang digunakan apakah sesuai dengan syariah atau tidak seperti yang dikatakan oleh ketua DPS H. Muhammad Aminudin sebagai berikut:

"Iyah itu kewajiban kami bahkan diBPRS itu ada produk yg harus melalui pengecekan terlebih dahulu mana yang sesuai mana yang tidak yg tidak direvisi yah sesuai lanjut bahkan ada terobosan-terobosan terbaru itu dicek karena ini syariah jadi harus trasparan format akad, ijab qobul siapa dan harussetidaknya mengenal atau tau kitab ta'lim agar tidak salah pengucapan bismillah pada saat akad dialmadinah sangat ketat".

5. Kegiatan transaksi dan semua aktivitas keuangan sesuai dengan standar akuntansi syariah

pada tahap ini bank melakukan kegiatan transaksi dan kegiatan kegiatan keuangan sesuai dengan standar akuntansi yang berlaku hal demikian bertujuan untuk meminimalisir kesalahan, kekeliruan ataupun kecurang yang terjadi. Hal ini dikatakan oleh ketua DPS H.Muhammad Aminudin sebagai berikut:

"yah menggunakan Akuntnsi yg terbaru dan menggunakan PSAK dan Bagian keuangan dan jajaran direksi keuangan”.

\section{Tahap Analisis pembiayaan murabahah}

Pada tahap analisis pembiayaan murabahah ini sangat penting untuk mengetahui apakah permohonan atau pengajuan calon nasabah diterima/layak atau ditolak. Hal ini disampaikan oleh dari bagian marketing Irman Nurdiana Okta menjelaskan sebagai berikut:

"Untuk proses pengajuan pembiayaan murabahah yang pertama yaitu pengisian formulir, lalu pengumpulan persyaratan, pengumpulan persyartan yang utama dalam proses pembiayaan murabahah adalah $R A B$, karena pembiayaan murabahah 
ini adalah akad jual beli jadi keperluan nasabah digunakan untuk apa, jika komoditi lebih dari satu missal untuk pembelian bahan bangunan sehingga pihak bank memerlukan RAB terlebih dahulu. Pengumpulan persyaratan diambil oleh Account Officer kemudian diberikan kebagian analis, dan dianalisis dalam segi 5C yaitu: Character, Capacity, Capital, Collecteral, condition. Setelah lulus dari 5C maka akad pembiayaan murabahah dapat berlangsung."

Pernyataan dari bagian marketing dipertegas oleh DPS bapak H.Aminullah sebagai berikut:

"calon nasabah atau nasabah datang langsung ke BPRS Al-Madinah untuk mengajukan permohonan, bank menerima permohonan nasabah dan memberikan persyaratan yang harus dipenuhi oleh nasabah dan memberikan informasi apa saja yang dibutuhkan oleh nasabah, jika kedua belah pihak menyetujui maka akan terjadi proses akad yang dilakukan antara bank dengan nasabah."

Adapun analisis penerapan sharia compliance dalam proses pembiayaan murabahah sebagai berikut :

1. Tidak boleh ada penambahan pendapatan secara tidak sah (Riba).

Tahap analisis ini digunakan untuk menghindari adanya penambahan pendapatan secara tidak sah (riba), pada BPRS Al-Madinah melakukan dengan cara musyawarah atau bank menentukan bagi hasil dan disepakati kedua belah pihak.Hal ini seperti dikatakan oleh ketua DPS H.Muhammad Aminudin sebagai berikut:

"bagi hasil di perbankan sudah punya acuannya tapi itu bisa dipermusyawarkan dan menguntungkankedua belah pihak tidak ada yang dirugikan."

Sebagaimana penjelasan pasal 2 undang-undang perbankan syariah tentang riba yaitu sebagai berikut:

"Riba yaitu penambahan pendaatan secara tidak sah (bathil) antara lain dalam transaksi pertukaran barang sejenis yang tidak sama kualitas, kuantitas, dan waktu penyerahan (fadhl), atau dalam transaksi pinjam-mminjam yang mensyaratkan nasabah penerima fasilitas mengembalikan dana yang diterima melebihi pokok pinjaman karena berjalannya waktu (nasi'ah)".

2. Tidak boleh ada transaksi untung-untungan (maisir)

Tahap ini menganalisis transaksi di BPRS Al-Madinah yang tidak merugikan salah satu pihak baik pihak nasabah atau pihak banksehingga tidak adanya transaksi untung-untungan (maisir)seperti yang dikatakan oleh ketua DPS H. Muhammad Aminudin sebagai berikut:

"Maisir itu kan adu, judi, bank syariah itu tidak ada unsur maisir ngundi nasib itu semua diharamkan dalam al-quran. apapun bentuk akadnya nanti kalau itu ada maka itu akan merusak bank syariah itu sendiri".

Sebagaimana penjelasan pasal 2 undang-undang perbankan syariah tentang maisir sebagai berikut:

"Maisir, yaitu transaksi yang digantungkan kepada suatu keadaan yang tidak pasti dan bersifat untung-untungan." 
3. Tidak boleh ada transaksi yang tidak jelas (gharar)

Tahap analisis ini digunakan untuk melakukan uji kebenaran data dan berfungsi untuk menghindari ketidakjelasan pada saat transaksi. Untuk menghindari ketidakjelasan BPRS AlMadinah menginformasikan seluruh informasi kepada calon nasabah. Hal ini dikatakan oleh H. Muhammad Aminudin sebagai berikut:

"Gharar itu kan penipuan atau tipu menipu barang jelek dibilang baik speak awal begini tapi yah begitu apapun penipuan apapun yg disampaikan berarti tidak sesuai dengan kenyataan”.

Sebagaimana penjelasan pasal 2 undang-undang perbankan syariah tentang gharar sebagai berikut:

"Gharar, yaitu transaksi yang objeknya tidak jelas, tidak dimiliki, tidak diketahui keberadaannya, atau tidak dapat diserahkan pada saat transaksi dilakukan kecuali diatur lain dalam syariah."

4. Produk yang dibiayai harus halal/ sesuai dengan syariah

Pada saat melakukan analisis bank harus yakin apakah produk yang dijual belikan halal atau haram. Sebagaimana penjelasan pasal 2 undang-undang perbankan syariah tentang haram sebagai berikut:

"Haram, yaitu transaksi yang objeknya dilarang dalam syariah"

Hal ini dipertegas oleh H. Muhammad Aminudin sebagai berikut:

"Iyah itu kewajiban kami jadi dibprs itu ada produk yg harus melalui pengecekan terlebih dahulu mana yang sesuai mana yang tidak yg tidak direvisi yah sesuai lanjut bahkan ada terobosan-terobosan terbaru itu dicek karna ini syariah jadi harus trasparan format akad, ijab kobul siapa dan harusmengenal atau tau kitab talim agar tidak salah pengucapan bismillah dial-madinah sangat ketat”.

Adapun Analisis yang digunakan untuk menentukan pembiayaan calon nasabah di teima atau tidaknya dilihat dari 5C (Character, Capacity, Capital, Collateral, and condition) yaitu sebagai berikut :

1. Character

Pada analisis chararter ini bertugas untuk mengetahui karakter atau watak dari calon nasabah. Analisis character dilakukan untuk meminimalisir penipuan atau ketidakjujuran calon nasabah. Seeperti yang dikatakan oleh Irman Nurdiana Okta sebagai berikut:

"character tersebut kira-kira bagaimana nah itu bisa dilihat dariIdeb Internasional debitur itu di web ojk asalnya sih system pembukuan operasi keuanganasalnya bei checking itu history nasabah apabila punya history pinjaman ke lembaga keuangan yang lain jadi itu bisa dilihat jadi tuh untuk penilaian karakter kalau misalkan si calon nasabah punya utang atau punya sangkut paut dengan yang lainkan bisa 
keliatan disitu ada bisa keliatan karakter ada lancar kurang lancar punya utang nanti bisa keliatan"

2. Capacity

Analisis capacity dilakukan untuk mengetahui kemampuan calon nasabah dalam membayar angsuran, analisis ini dapat dilakukan dengan melihat laporan keuangan calon nasabah yaitu pada pendapatan dan pengeluaran dan juga untuk melihat banyaknya kewajiban yang ditanggung. Seperti yang dikatakan oleh Irman Nurdiana Okta sebagai berikut:(halaman:70)

"dilihat dari Ideb Internasional debitur itu di web ojk asalnya sih system pembukuan operasi keuangan asalnya bei checking itu history nasabah apabila punya history pinjaman ke lembaga keuangan yang lain”.

3. Capital

Pada tahap capital ini dilakukan untuk melihat apakah calon nasabah memiliki asset selain pendapatan dari pekerjaannya sehingga bank dapat meminimalisir kerugian.Seperti yang dikatakan oleh Irman Nurdiana Okta sebagai berikut:

Pernyataan 1 “...sumber pengembalian nantikan disalah satu persyaratan ada atau untuk pengajuan murabahah itu sumber penghasilannya dari mana apakah dari gaji kalau misalkan seorang pegawai ataukah dari hasil usaha dari usaha kalau dilihat dari penghasilan dari kita sih diambil dulu untuk keperluan kehidupan si nasabah.." Pernyataan 2 "...dari sampingan berapa dicatat dikasih angkanya berapa dari sampingn tersebut kalau masih minus berarti tidak masuk, jadi kalau masih kurang di tanyakan dulu punya sampingan gak, kalau punya sebutin ."

4. Collateral

Pada tahap analisis collateral digunakan untuk melihat nilai jaminan yang akan diserahkan kepada bank untuk miminimalisir penipuan yang dilakukan oleh nasabah dan jaminan yang digunakan oleh nasabah tidak boleh lebih ataupun kurang dari harga pembiayaan. Seperti yang dikatakan oleh irman Nurdiana okta sebagai berikut:

"collateral agunan, nah kalau agunan misalkan 70\% dari angka pasaran kendaraan tersebt kalau misalkan dia ngajuin mobil avanza kisaran 100 jutaan atau 200 jutaan avanza itu bisa dijadikan agunan itu kan ngambil maksimal dari agunan tersebut 100 juta dari $70 \%$ jadikan 70 juta maksimal”,

\section{Condition}

Pada analisis condition ini berguna untuk melihat kondisi financial atau perekonomian calon nasabah sehingga bank dapat menentukan biaya angsuran sesuai dengan kondisi calon nasabah. Seperti yang dikatakan oleh irman nurdiana okta sebagai berikut:

"usaha dengan kondisi saat ini korona secara ekonomi kan turun semua sector juga berpenagruh juga dengan penghasilan makanya untuk sekarang dari kami untuk bmkm seperti yang dihimbaukan oleh P2O untuk berhati2 untuk pembiayaan saat ini karena ekonomi lagi turun". 


\section{Tahap Monitering dan Evaluasi pembiayaan murabahah}

Tahap ini sangat penting dilakukan untuk pemantauan pada saat pasca pembiayaan, tahap ini bertujuan untuk memantau nasabah dalam melunasi angsuran pembiayaan sehingga bank harus menjalin silaturahmi dengan nasabah agar pembayaran dapat dipantau oleh bank.Jika nasabah tidak dapat melakukan pembayaran maka bank harus memiliki solusi pada setiap kendala yang dialami oleh nasabah. Seperti yang dikatakan oleh irman nurdiana okta sebagai berikut:

"bank tidak mengenakan denda bagi nasabah yang menunda pembayaran namun bank akan melakukan kunjungan ke nasabah dan menanyakan permasalahan yang dihadapi oleh nasabah, dan bank juga memberikan opsi ke nasabah untuk meringankan pembayaran dan apabila nasabah melunasi secara cepat bank memberikan potongan/diskon kepada nasabah yang melunasi lebih cepat dari waktu yang disepakati, namun potongan tersebut tidak dijanjikan kepada nasabah pada saat akad berlangsung."

Dipertegas oleh H.Muhammad Aminudin sebagai berikut:

"Iyah ada ketika ada niatan baik untuk melunasi secara cepat maka adanya keringan keringan tertentu. Dibicarakan waktu akad dan sudah diatur dlm fatwa MUI”

Selain itu pada tahap ini juga DPS mengevaluasi kegiatan operasional BPRS Al-Madinah Tasikmalaya dan memeriksa dengan menanyakan kepada bank jika terjadi ketidaksesuaian pada saat monitoring dan kegiatan dilapangan maka akan dilakukan audit. Seperti yang dikatakan oleh ketua DPS H.Muhammad Aminudin sebagai berikut:

"Dalam melakukan pengawasan yang pertama kita kan ada istilah kode etik tata kelola tata kerja. Satu bulan sekali untuk rapat rutin memantau progress kemudian enam bulan sekali laporan per-dps pusat ojk sudah diatur dalam regulasi nya jadi kami tidak bisa melanggar aturan yang ada."

\section{Pembiayaan murabahah sudah sesuai dengan sharia compliance}

Berdasarkan hasil dari analisis penerapan sharia compliance pada pembiayaan murabahahdi BPRS Al-Madinah Tasikmalaya sebagai berikut:

Tabel 4.2.analisis pembiayaan murabahah berdasarkan sharia compliance

\begin{tabular}{|l|l|l|l|l|l|}
\hline No & Sharia compliane berdasarkan fatwa DSN- & \multicolumn{3}{|l|}{ Pembiayaan Murabahah } \\
\cline { 2 - 6 } & MUI & M1 & M2 & M3 & M4 \\
\hline 1. & $\begin{array}{l}\text { Tidak boleh ada penambahan pendapat secara } \\
\text { tidak sah (Riba). }\end{array}$ & $\checkmark$ & & $\checkmark$ & \\
\hline 2. & $\begin{array}{l}\text { Tidak boleh ada transaksi untung-untungan } \\
\text { (maisir) }\end{array}$ & & $\checkmark$ & $\checkmark$ & \\
\hline
\end{tabular}




\begin{tabular}{|l|l|r|r|r|r|}
\hline 3. & $\begin{array}{l}\text { Tidak boleh ada transaksi yang tidak jelas } \\
\text { (gharar). }\end{array}$ & $\checkmark$ & $\checkmark$ & $\checkmark$ & \\
\hline 4. & $\begin{array}{l}\text { Tidak boleh objek transaksi yang dilarang } \\
\text { dalam syariah (haram) }\end{array}$ & $\checkmark$ & $\checkmark$ & $\checkmark$ & \\
\hline 5. & $\begin{array}{l}\text { Tidak boleh ada ketidakadilan bagi pihak lain } \\
\text { (zalim) }\end{array}$ & $\checkmark$ & & & \\
\hline 6. & Terdapat Dewan Pengawas Syariah (DPS) & $\checkmark$ & $\checkmark$ & & $\checkmark$ \\
\hline
\end{tabular}

Sumber : Data Diolah

Keterangan :

1. M1 : pengajuan pembiayaan murabahah

2. M2 : pelaksanaan pembiayaan murabahah

3. M3 : Analisis dalam pembiayaan murabahah

4. M4 : Evaluasi atau monitoring

\section{SIMPULAN}

Penelitian yang berjudul "Penerapan sharia compliance dalam meningkatkan efektivitas pembiayaan murabahah" pada BPRS Al-Madinah Tasikmaaya. Pada pembahasan ini peneliti menyimpulkan bahwa :

1. Penerapan sharia compliance pada pembiayaan murabahah di BPRS Al-Madinah Tasikmalaya melalui beberapa tahapan yaitu: Tahap pertama yaitu tahap pengajuan, tahap pengajuan merupakan tahap permohonan yang dilakukan oleh nasabah pada BPRS AlMadinah Tasikmalaya dan pihak BPRS Al-Madinah Tasikmalaya memberikan formulir serta persyaratan yang akan digunakan dalam pembiayaan murabahah. Tahap kedua yaitu tahap pelaksanaan, tahap pelaksanaan merupakan tahap dimana nasabah memberikan atau menyerahkan dokumen atau persyaratan yang dibutuhkan dalam pembiayaan murabahah serta melampirkan RAB untuk dianalisis oleh pihak BPRS Al-Madinah Tasikmalaya apakah permohonan nasabah diterima atau tidak, apabila diterima maka akan melakukan akad pembiayaan murabahah jika permohonan ditolak maka pihak BPRS Al-Madinah Tasikmalaya akan memberikan alasan kenapa permintaan tidak diterima. Tahap ketiga yaitu tahap analisis, tahap analisis merupakan tahap dimana BPRS Al-Madinah Tasikmalaya menganalisi RAB dan persyaratan yang diajukan oleh pihak nasabah, apabila dokumen yang diserahkan sudah memenuhi persyaratan dan tidak ada permasalahan maka permohonan dari pihak nasabah diterima dan pihak BPRS menghubungi nasabah untuk melakukan akad, apabila permohonan ditolak maka pihak nasabah memberi tahukan alasan mengapa permohonan ditolak. Tahap yang terakhir yaitu tahap monitoring dan Evaluasi, tahap ini dilakukan untuk memantau nasabah dalam melunasi angsuran pembiayaan dengan selalu menjaga silaturahmi dengan 
nasabah. Tahapan-tahapan tersebut sudah sesuai dengan sharia compliance dilihat dari prinsip-prinsip syariah yaitu : riba, maisir, gharar, haram dan dzolim.

2. Pembiayaan murabahah pada BPRS Al-Madinah Tasikmaya sudah sesuai dengan sharia compliance berdasarkan prinsip-prinsip syariah yang tertera pada Pasal 2 Undang-Undang No. 21 Tahun 2008 yaitu : riba, maisir, gharar, haram dan dzolim. Pada tahap-tahap pembiayaan murabahah yaitu tahap pengajuan, tahap pelaksanaan, tahap analisis dan tahap evaluasi atau monitoring pembiayaan murabahah di BPRS Al-Madinah Tasikmalaya bahwa tidak adanya unsur-unsur yang menyalahi prinsip syariah yang tertuang pada undang-undang perbankan syariah.

\section{DAFTAR PUSTAKA}

Anggraeni, Windi Ariesti. (2019). Social Performance pada Perbankan syariah Indonesia: Sharia Enterprise Theory Perspective. Jurnal Wacana Ekonomi Vol.18, No. 02 Tahun 2019

Antonio, Muhammad syafi'I, banks yariah dari teori ke praktik (cet.1; Jakarta; Gema Insani Press,2001)

Baehaqi, Jafar (2017). Kerangka Yuridis Kepatuhan Syariah dalam Operasional Perbankan syariah di Indonesia. Jurnal Hukum dan Perundangan Islam Vol. 7 No. 1 April 2017

Djayusman, Royyan Ramdhani (2012). Murabahah antara Teori dan Praktek: Analisis Fiqih dan Keuangan. Jurnal Hukum dan Ekonomi Islam Vol.6 No.2.

Fatwa DSN No.04/DSN/MUI/IV/2000, Tanggal 1 April 2000 tentang murabahah sebagai landasan dalam syariah dalam transaksi murabahah.

Hafidz, Muhammad (2018), Studi Penerapan Sharia Compliance Dalam Proses Pembiayaan Murobahah Di Bank Syariah Mandiri KCP Kaliurang Jogjakarta. Skripsi Muhammad Hafidz 2018 Universitas Islam Indonesia.

Haryadi, Bambang. (2010). Political Economy of Sharia Accounting (Membangun Teori Ekonomi Politik Akuntansi Syariah). Malang: Pascasarjana Universitas Brawijaya

Ismail, perbankan syariah Jakarta:kencana Prenada media grup 2011

Kalbarini, Rahmah Yulisa, (2018). Implementasi Akuntabilitasi dalam Sharia Enterprise Theory di lembaga bisnis syariah. Jurnal Ekonomi dan Bisnis islam Vol.4, No.1 2018

Khaira. Anisa (2014). Analisis Kepatuhan Bank Syariah Terhadap Prinsip-Prinsip Syariah Pada Pembiayaan Murabahah. Skripsi Anisa Khaira Tahun 2014 Universita Pendidikan Indonesia. 
Latif, Abdul (2016). Implementasi Fatwa DSN MUI Terhadap praktik pembiayaan Murabahah Bank Syariah Mandiri dan Bank Muamalat KCP Ponorogo. Jurnal muslim heritage, Vol.1 No.1, Mei-Okt 2016.

Mahmudi, (2011). Akuntansi Sektor Publik. UII Press, Yogyakarta

Masni (2018) penerapan sharia compliance dalam produk bank syariah mandiri dipolewalimandar. Skripsi Masni Institut Agama Islam Negeri (IAIN) parepare

Mauluddin, M. Sholeh (2018). Pembiayaan Murabahah Dalam Perspektif Fatwa DSN-MUI. Jurnal Qawanin Vol.2 No.1 januari 2018

Meutia, I. (2010). Menata Pengungkapan CSR Di Bank Islam (Suatu Pendekatan Kritis). Jakarta: Citra Pustaka Indonesia

Muhammad, Manajemen Pembiayaan Bank Syari"ah (Yogyakarta: UPP AMP YKPN, 2005).

Nurbaity, Alfira Febbytia (2019). Analisis Penerapan Sharia Compliance pada pembiayaan Murabahah dan Ba'I Bitsaman Ajil di KSPS BMT Ramadana Salatiga. Skrispsi Alfira Febbytia Nurbaity tahun 2019 Institut Agama Islam Negeri Salatiga.

Suhendi, Hendi. Fiqih muamalah Jakarta: Pt Raja Grafindo Persada 2005

Sutedi, Adrian. (2009) Perbakan Shari"ah, Tinjauan dan Beberapa Segi Hukum (Jakarta: Ghalia Indonesia, 2009).

Umam, Khotibul S.H.,LL.M. Trend Pembentukan Bank Umum Syariah pasca Undang-Undang Nomor 21 tahun 2008 (konsep, regulasi, dan implementasi), Yogyakarta: BPFE Yogyakarta , 2009.

Waluyo, Agus (2016). Kepatuhan Bank Syariah Terhadap Fatwa DSN Pasca Transformasi Ke Dalam Hukum Positif. Jurnal penelitian sosial keagamaan Vol.10 No. 2, Desember 2016.

Wangsawidjaya Dr. A (2012). Pembiayaan Bank Syariah, Jakarta: PT. Gramedia Pustaka Utama, 2012

Yustina, Prita Andini, (2016). Pengaruh Sharia Compliance (Kepatuhan Syariah) dan Pelayanan Terhadap Loyalitas Nasabah PT. BPRS Lantabur Tebuireng Cab. Mojokerto. Tesis Program Magister Ekonomi Syariah, Surabaya, 2016.

Zubairi, Hasan, (2009). Undang-Undang Perbankan Syariah titik temu hukum islam dan hukum nasional, Jakart:PT RajagrafindoPersada,2009.

Aminuddin, Muhammad, (2020). ketua Dewan pengawas Syariah (DPS) BPRS Al-Madinah Tasikmalaya

Okta, Irman Nurdiana, (2020). Funding \& collector BPRS Al-Madinah Tasikmalaya 
Jurnal Ekonomi Perjuangan ( JUMPER )

Volume 2 Nomor 1, Juli 2020

p-ISSN : 2714-8319,e-ISSN: 2714-7452

Oman, (2020). Nasabah pembiayaan murabahah BPRS Al-Madinah tasik. 
JUMPER Volume 2 Nomor 1, Juli 2020

p-ISSN : 2714-8319,e-ISSN: 2714-7452

56 J Jurnal Ekonomi Perjuangan (JUMPER) 